\title{
КОНЦЕПЦІЯ ОСВІТИ ДІТЕЙ РАННЬОГО ТА ДОШКІЛЬНОГО ВІКУ: НОВИЙ ПОГЛЯД
}

\author{
Наукова доповідь на засіданні Президії НАПН України 27 лютого 2020 р.
}

https://doi.org/10.37472/2707-305X-2020-2-1-2-2

\section{СИСОЄВА}

Світлана Олександрівна доктор педагогічних наук, профресор, дійсний член (академік) НАПН України, академік-секретар Відділення загальної педагогіки та філософрії освіти Національної академії педагогічних наук України, м. Київ, Україна

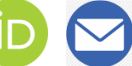

\section{РЕЙПОЛЬСЬКА}

\section{Ольга Дмитрівна} кандидат педагогічних наук, дочент, завідувач лабораторії дошкільної освіти і виховання Iнституту проблем виховання Національної академії педагогічних наук України, м. Київ, Україна

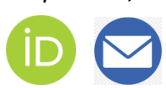

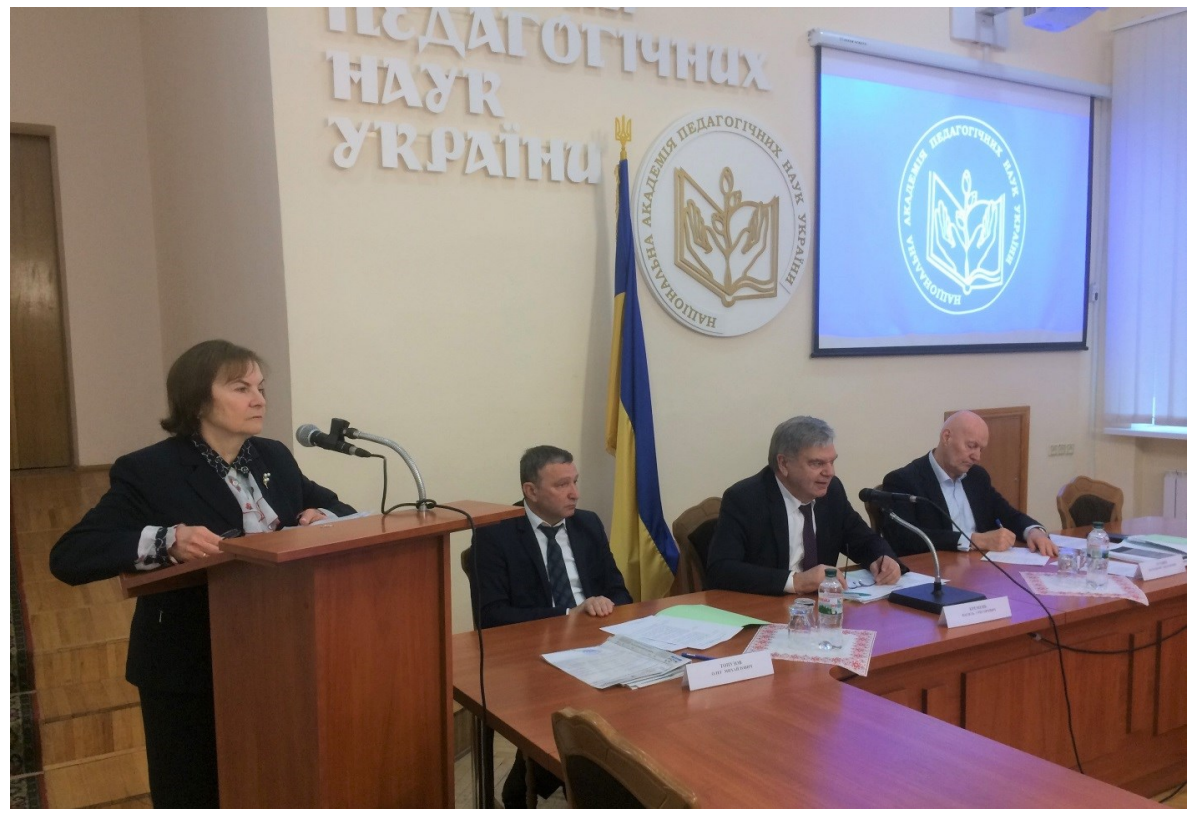

Анотація. Представлено головні положення проєкту Концепиії освіти дітей раннього та дошкільного віку, яку розглянуто на засіданні Президії НАПН України 27 лютого 2020 р., та оприлюднено для громадського обговорення на вебсайті НАПН України. У доповіді-презентації розкрито мету Концепиії, яка полягає у забезпеченні системних змін в освіті дітей раннього та дошкільного віку, управлінні системою дошкільної освіти на різних їі рівнях задля формування стратегічного ресурсу країни - якісного людського капіталу. Обгрунтовано актуальність і доцільність Кониепції, наведено чітко вибудовану ії структуру та охарактеризовано п'ять розділів: "Стан освіти дітей раннього та дошкільного віку в Україні»; "Стратегічні напрями розвитку освіти дітей раннього та дошкільного віку»; "Законодавчі й управлінські передумови реалізації концепції»; "Фінансування»; "Очікувані результати»; "Ризики, пов'язані з реалізацією концепиії» та списку використаних термінів. Концептуальні засади модернізації системи дошкільної освіти розроблені з ініціативи вчених НАПН України та законотвориів, а також за участю науково-педагогічних працівників і освітян. 3поміж авторів / укладачів проєкту Концепиії: В.А. Воронов, голова підкомітету з питань раннього розвитку та дошкільної освіти Комітету Верховної Ради України з питань освіти, науки та інновацій; Н.В. Гавриш, гол. наук. співр. лабораторії дошкільної освіти і виховання Інституту проблем виховання НАПН України, докт. пед. наук, професор; Л.В. Канішевська, заступник директора з науково-експериментальної роботи Інституту проблем виховання НАПН України, докт. пед. наук, профессор; Т.О. Піроженко, завідувачка лабораторії психології дошкільника Інституту психології імені Г.С. Костюка НАПН України, докт. психол. наук, професор, член-кореспондент НАПН України; О.Д. Рейпольська, завідувачка лабораторії дошкільної освіти і виховання Інституту проблем виховання НАПН України, канд. пед. наук, дочент; С.О. Сисоєва, академік-секретар Відділення загальної педагогіки та фрілософії освіти НАПн України, докт. пед. наук, професор, дійсний член (академік) НАПН України.

Ключові слова: батьківське партнерство; дитиночентризм; заклади дошкільної освіти; освіта дітей раннього віку; психолого-педагогічний супровід; ранній вік; якість дошкільної освіти. 
Ранній розвиток дитини розглядається як одна з найбільш економічно ефективних інвестицій у людський капітал, що зумовлює сталий розвиток країни. Діяльність розвинутих країн і країн, що розвиваються, показує, що інвестиції у перші роки життя дитини сприяють збільшенню сімейного доходу та зростанню добробуту суспільства і держав (UNICEF, 2013).

У цьому контексті цікавим $є$ звіт Організації економічного співробітництва та розвитку (ОЕСР, OECD) про стан освіти та піклування за дітьми раннього віку (The early childhood education and care, ECEC) у центрах раннього розвитку дітей дев'яти країн світу (Чилі, Данії, Німеччині, Ісландії, Ізраїлю, Японії, Кореї, Норвегії та Туреччині). Це перше міжнародне опитування, яке підтвердило тезу, що «якісна рання освіта та піклування $€$ важливими для дітей, сімей і суспільств»). Водночас це визначило низку проблем щодо ресурсного забезпечення практик організації освіти для дітей раннього віку (OECD, 2019).

Відповідно до Міжнародної стандартної класифікації освіти, МСКО (International Standard Classification of Education, ISCED), нульовий рівень освіти (level 0 - Early childhood education) «освіта дітей раннього віку» охоплює два стратегічно важливих для усього подальшого життя людини періоди: ранній вік (від народження до трьох років) і дошкільний вік (від трьох до шестисеми років), у якому особливе місце посідає передшкільний період, що збігається зі старшим дошкільним віком (ISCED, 2011, с. 26-29).

В Україні з 1992 р. діючою є стаття 179 Кодексу законів про працю України, яка визначає право

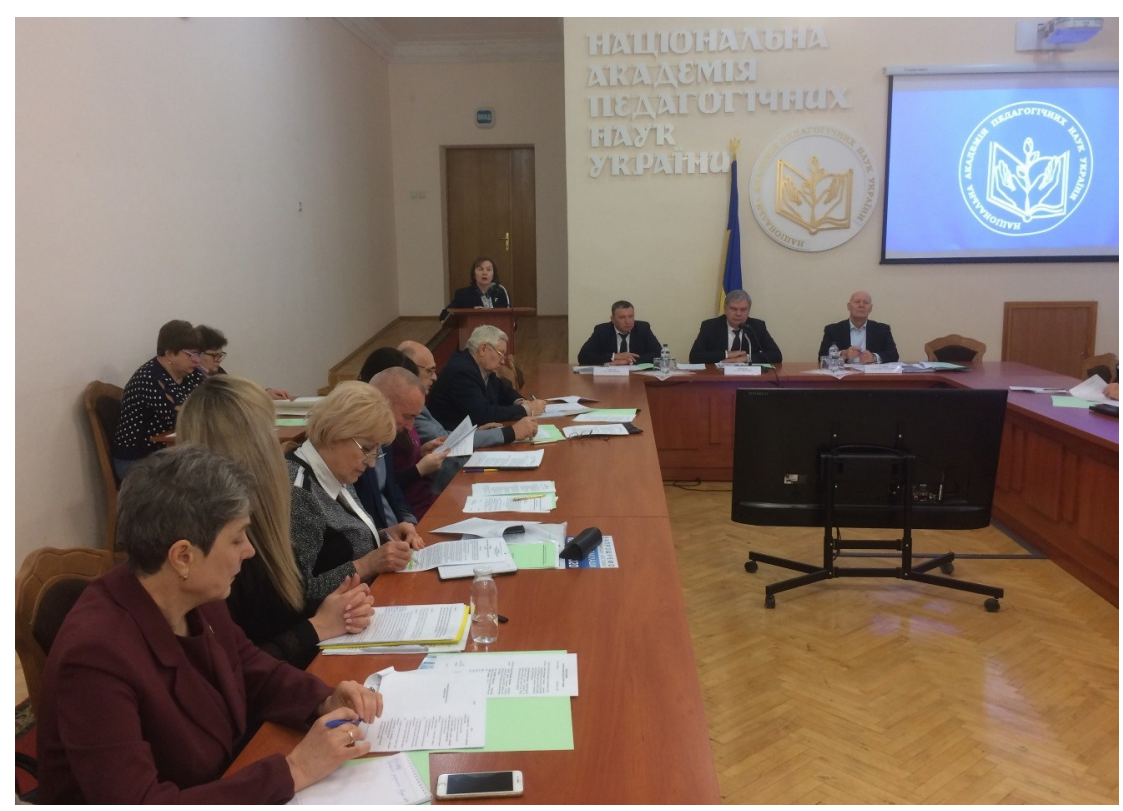

жінки перебувати у відпустці по догляду за дитиною до трьох років (Кодекс законів, 1971 р., зі змінами 1991-2020 рр., ст. 179). 3 моменту прийняття цієї законотворчої ініціативи у нашій країні почала стрімко скорочуватися мережа груп для дітей раннього віку.

Соціальна (частково оплачувана) відпустка сприймається у суспільстві як державна гарантія додаткової соціальної допомоги матері (сім'ї) здійснювати догляд за дитиною до трьох років. Однак догляд не завжди є належним для збереження здоров'я дитини, а домашнє піклування унаслідок низької загальної і недостатньої педагогічної культури деяких батьків не забезпечує повноцінний розвиток дітей раннього та дошкільного віку.

У XXI столітті змінюється не тільки загальний устрій світу, а й погляди на значення дошкільної освіти як освітньої послуги, що має бути доступною, якісною, високопрофесійною і ефективною для кожного громадянина, громади, держави і суспільства.

Науковці і педагоги звертають увагу на кризові явища у процесі розвитку дитини раннього віку, яка виховується удома без належного педагогічного супроводу. Навіть у благополучній сім'ї не враховують особливості темпоритму життя малюків. Надмірне використання батьками різноманітних електронних пристроїв як засобів розваги дітей робить малюків залежним від гаджетів і ускладнює їх орієнтацію у реальному світі.

Відповідно до Закону України «Про дошкільну освіту» (2001р.) дошкільна освіта є обов'язковою первинною складовою частиною системи безперервної освіти в Україні. Базовими етапами фізичного, психічного та соціального становлення особистості дитини визначено вік немовляти (до одного року, ранній вік (від одного до трьох років) і передшкільний вік («Про дошкільну освіту», 2001 р., зі змінами 2020 р., ст. 4). Завдання дошкільної освіти, виконання яких за Законом покладається на сім'ю, батьків і дошкільні заклади освіти, передбачають забезпечення якості і професійного 


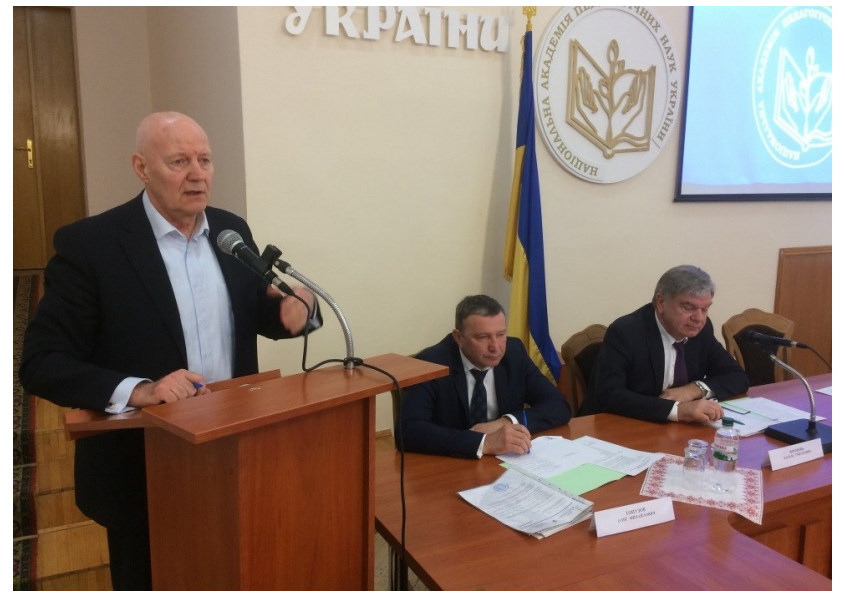

супроводу розвитку дітей у системі дошкільної освіти.

На початку третьої декади XXI століття вітчизняна дошкільна освіта як галузь освіти потребує системних перетворень і змін, пов'язаних із новими вимогами до освіти дітей раннього та дошкільного віку і діяльності дошкільних закладів. Тож, Україні необхідна нова стратегія освіти дітей раннього і дошкільного віку, яка має бути предметом консенсусу суспільства, науковців, педагогів дошкільної освіти, дітей і їхніх батьків.

Новий погляд на дошкільну освіту - це розуміння і сприйняття напрямів освітнього розвитку дітей від народження до шкільного віку на засадах дитиноцентризму відповідно до викликів змінного глобалізованого світу, цифрового суспільства та очікувань громадян України. Суспільству потрібні практичні державницькі рішення для створення оптимальних умов життєдіяльності та освітнього розвитку дітей у сім'ї та закладах дошкільної освіти. Підвищення соціального статусу педагога і покращення іміджу професії вихователя неможливі без створення державою необхідних умов і додаткових соціальних гарантій.

За даними Державної служби статистики України, станом на 1 січня 2019 р., в Україні функціонує 14 тис. закладів дошкільної освіти (юридичних осіб), у яких виховується 1,3 млн дітей. 3 них у містах функціонує 5,8 тис. закладів (39\%), у яких виховується 970 тис. дітей (75,9\%). У сільській місцевості - 9,1 тис. закладів (61 \%), де виховується 309 тис. дітей (24,1\%) (Концепція, 2020).

Визнаючи позитивну динаміку розвитку галузі дошкільної освіти (розширення мережі різних типів закладів дошкільної освіти; осучаснення змісту і упровадження педагогічних технологій на засадах дитиноцентризму, природовідповідності; оновлення програмно-методичного забезпечення тощо), не можна нехтувати соціальноекономічними, культурологічними й іншими викликами, які гальмують процеси змін. 3-поміж основних автори Концепції відзначили такі: неузгодженість правових, економічних, соціально -психологічних аспектів функціонування системи освіти дітей раннього та дошкільного віку; нерозвиненість приватного сектору; перевантаження груп дітей раннього та дошкільного віку у більшості закладів дошкільної освіти.

«Суттєвою прогалиною сучасної дошкільної освіти України $€$ відсутність системи суспільних впливів на ранній розвиток дитини від народження до трьох років» (Концепція, 2020). Дошкільною освітою майже не охоплені діти раннього віку, зокрема лише 20 дітей до одного року відвідують заклади дошкільної освіти. Показники охоплення дітей раннього віку (від 0 до двох років) становлять 14,6\% від загальної чисельності населення цього віку. Охоплення дітей дошкільного віку (три-п'ять років) - на рівні 74,4\% (у містах $83,7 \%$, у сільській місцевості-56,2\%).

Незважаючи на збільшення протягом 20162017 рр. мережі закладів дошкільної освіти, проблемою для багатьох громад $€$ великі черги на місця для дітей у таких закладах.

За даними Державної служби статистики України станом на кінець 2018 р. бракує фахівців дошкільної галузі. у 2017/2018 н.р. у закладах дошкільної освіти працювало 137,7 тис. осіб; 64,5 \% педагогів здобули вищу освіту за першим (бакалаврським), другим (магістерським) рівнями або за освітньо-кваліфікаційним рівнем спеціаліста. Тож статистичні дані свідчать, що майже третина від загальної кількості педагогічних

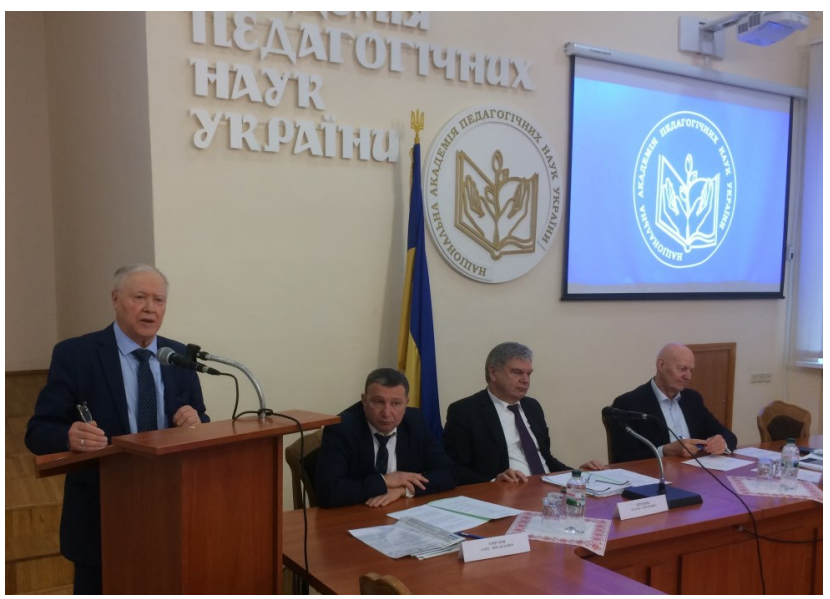




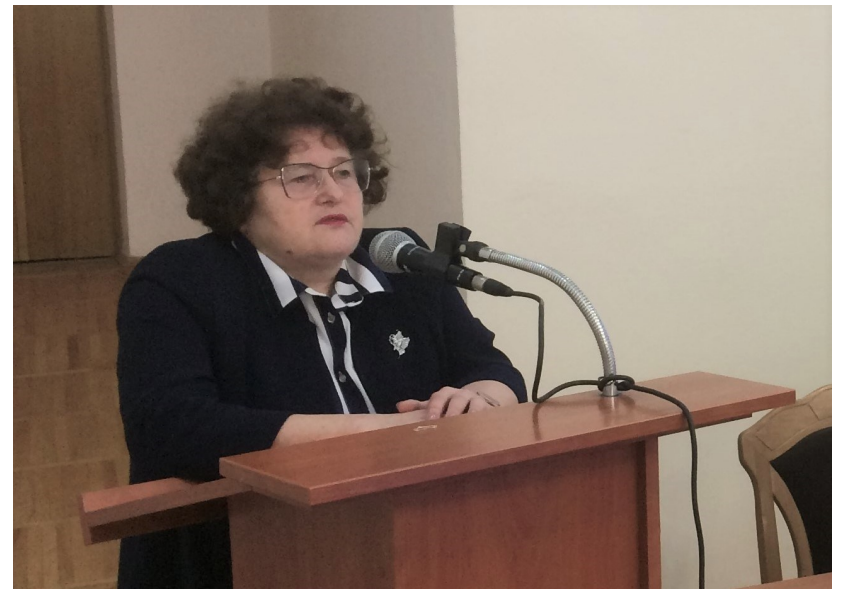

працівників закладів дошкільної освіти потребують підвищення рівня освіти.

3 метою розробки концептуальних засад модернізації системи дошкільної освіти з ініціативи вчених НАПН України та В.А. Воронова, голови підкомітету з питань раннього розвитку та дошкільної освіти Комітету Верховної Ради України з питань освіти, науки та інновацій, проведено низку комунікативних заходів з участю учених, науково-педагогічних працівників і педагогів дошкільної освіти. Результатом плідної і злагодженої роботи науковців НАПН України, законотворців (підкомітет з питань раннього розвитку та дошкільної освіти), науковопедагогічних працівників і освітян $є$ проєкт Концепції освіти дітей раннього і дошкільного Biky.

Концепція має чітку структуру і складається з п'яти розділів: «Стан освіти дітей раннього та дошкільного віку в Україні»; «Стратегічні напрями розвитку освіти дітей раннього та дошкільного віку»; «Законодавчі й управлінські передумови реалізації концепції»; «Фінансування»; «Очікувані результати»; «Ризики, пов'язані 3 реалізацією концепції» та списку використаних термінів.

\section{Нові орієнтири і цінності дошкільної освіти}

Теоретико-методологічне ядро Концепції становлять: філософське осмислення освіти як соціокультурного феномену, в якому пріоритетними є цінності гуманізму, людяності, толерантності, соціальної відповідальності; особистісний, діяльнісний та компетентнісний підходи; дитиноцентрична модель освітнього простору.

Гасло Концепції освіти дітей раннього та дошкільного віку (далі - Концепція) - docmynність та якість освіти для дітей раннього та дошкільного віку - шлях до сталого розвитку та якісного людського капіталу України.
Високе призначення, відповідальність держави, наголошено у Концепції, полягає у забезпеченні умов для всебічного та гармонійного розвитку дітей раннього та дошкільного віку, їхньої соціалізації на основі консолідації зусиль усіх соціальних інститутів.

У візії автори-розробники заклали комплексне уявлення про дошкільну освіту як стартову платформу для подальшої освіти упродовж життя, першу обов'язкову сходинку у системі неперервної освіти, фундамент формування людського капіталу суспільства.

Місія, цінності та візія дошкільної освіти $\epsilon$ дороговказом для всіх суб'єктів на шляху до розвитку якісної освіти дітей раннього та дошкільного віку за умови активної позиції дитини в освітньому процесі та з урахуванням інших пріоритетів.

Автори Концепції визначають аксіологічні домінанти дошкільної освіти як передумови повноцінного подальшого розвитку людини на всіх етапах іï життя: визнання самоцінності раннього і дошкільного дитинства; щасливе проживання дошкільного дитинства; фізичне, психічне та соціальне здоров'я дитини; повага до дитини та особливостей їі розвитку.

Аксіологічна модальність дошкільної освіти у Концепції розгортається, коли йдеться про цінності вікових періодів розвитку дитини:

- період від народження до трьох років $\epsilon$ унікальним, найбільш інтенсивним й визначальним у розвитку людини; ключовим у загальному перебігу психофізичного й соціального розвитку дитини; найбільш сприятливим для соціальних і педагогічних впливів, інтенсивного розвитку мовлення, пам'яті, образної уяви та мислення;

- дошкільна освіта (від трьох до шести-семи років) спрямована на особистісне зростання

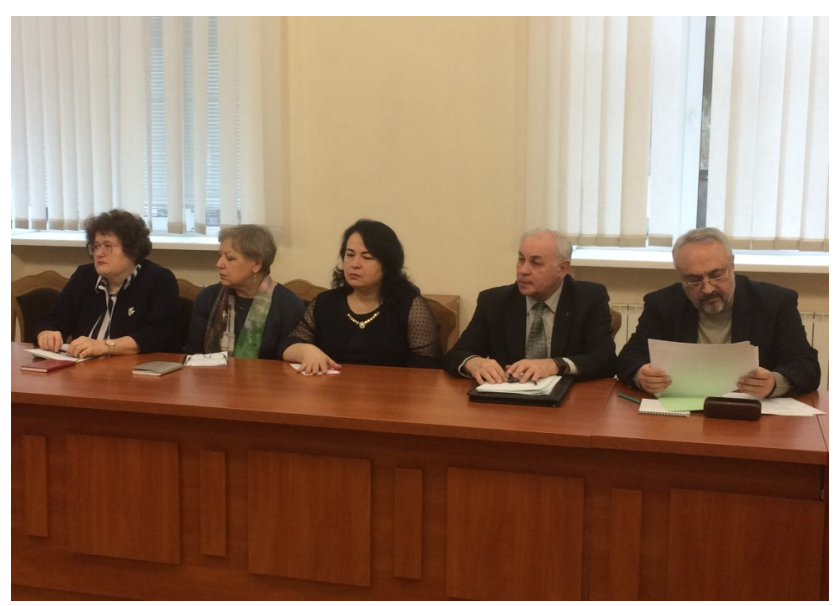




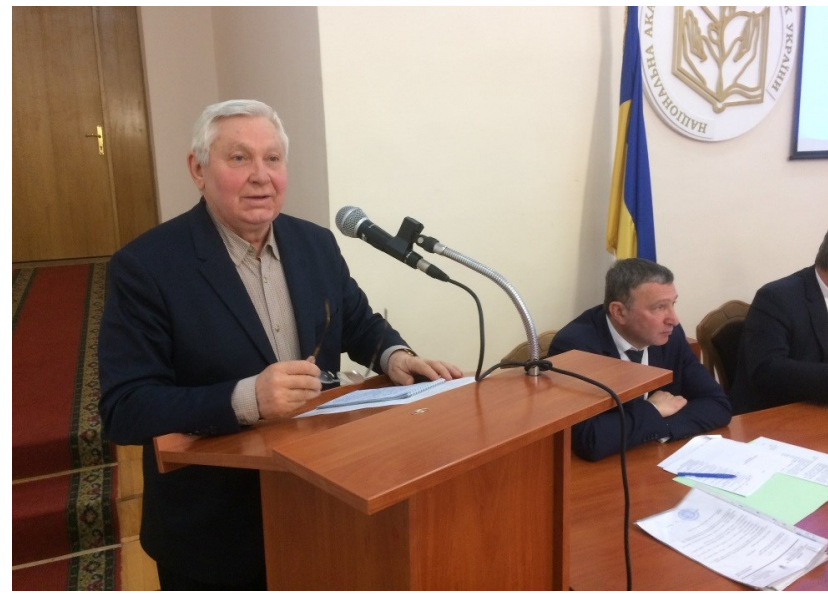

дитини, набуття дошкільної зрілості в різних видах дитячої діяльності, формування базових компетентностей: комунікації, креативності, критичного мислення тощо.

Концепція освіти дітей раннього і дошкільного віку: стратегія змін

Концепція охоплює основні напрями розвитку освіти дітей раннього та дошкільного віку: забезпечення рівного доступу і розвиток мережі закладів дошкільної освіти; державногромадське та державно-приватне партнерство в управлінні дошкільною освітою, соціальна підтримка батьківського партнерства; забезпечення якості дошкільної освіти відповідно до визначених стандартів, обов'язкова умова якої професійна компетентність педагогів; збереження фізичного, психічного та соціального здоров' я дітей; наукове забезпечення розвитку дошкільної освіти.

Однім із пріоритетів Концепції $є$ гарантування рівного доступу до якісної освіти всіх дітей раннього та дошкільного віку, зокрема і з особливими освітніми потребами (обдарованих дітей та тих, хто має ментальні або фізичні порушення).

Для досягнення цієї мети пропонується запровадити механізми розвитку приватного сектору дошкільної освіти паралельно із державною системою дошкільної освіти. На часі й розвиток неформальної дошкільної освіти, розширення форм організації дошкільної освіти: відкриття додаткових груп у функціонуючих закладах дошкільної освіти, зокрема груп 3 короткотривалим перебуванням тощо.

Концепція також передбачає нормативноправове забезпечення інклюзивної освіти для дітей раннього та дошкільного віку відповідно до міжнародних зобов'язань України у сфері прав людини, а також упровадження системи фінансу- вання додаткових послуг для дітей з особливими освітніми потребами, зокрема через надання спеціальних субвенцій.

Організація освітнього процесу та освітнього середовища, орієнтованих на інтеграцію дітей 3 особливими освітніми потребами в дитячу спільноту, психолого-педагогічний супровід і комплексне медико-педагогічне оцінювання розвитку дітей пропонуються як заходи для забезпечення конституційного права дитини на освіту і рівного доступу до якісної дошкільної освіти.

Оновлений інтегрований зміст передшкільної освіти в контексті завдань Нової української школи потребує таких моделей освітнього процесу (ігрова, проєктна, середовищна та ін.), що будуються на принципах пріоритету досвіду над інформуванням, партнерської взаємодії, активізації власних зусиль дитини, діалогового формату освітнього процесу тощо.

Автори Концепції вказують на важливість застосування широкої палітри форм і методів організації діяльності дітей (пізнавальна, мовленнєва, рухова, продуктивна, художньо-естетична, ігрова тощо). Залучення дитини у різні види діяльності надає можливості для самопізнання самовизначення у різних соціокультурних співтовариствах - групах одноліток, різновікових групах, серед друзів, дорослих. Активна участь у полілогах, досліди та експериментування, екскурсії, творча командна робота, інтерактивні методи навчання скеровують на формування у дитині базових особистісних якостей (активності, самостійності, ініціативності, креативності, відповідальності тощо).

Дошкільна освіта: партнерство розширених можливостей держави, суспільства і батьків

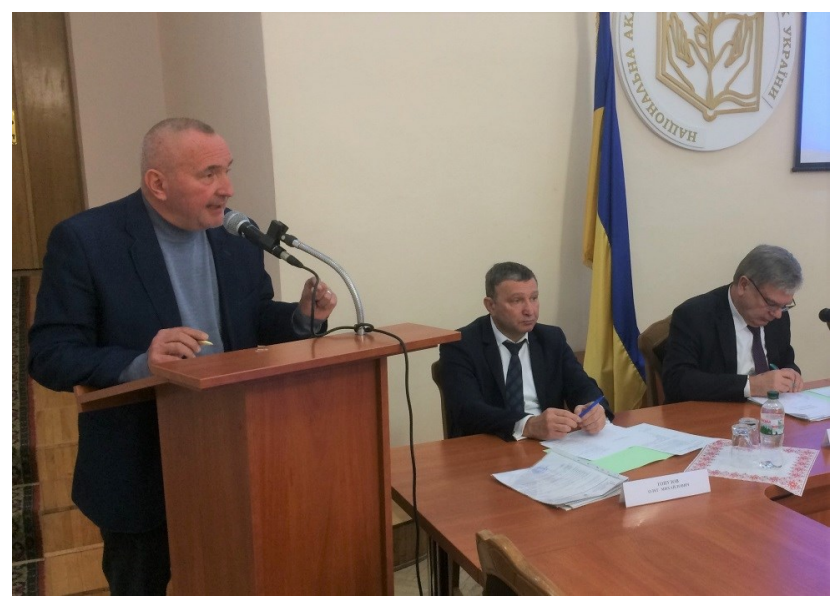


Інтенсивність розвитку суспільства періоду нанотехнологій, digital- та IT-технологій, сучасні тенденції безперервної освіти (зокрема дошкільної як ії складової) вимагають налагодженої співпраці й ефективної комунікації між різними групами на основі партнерства, конструктивного діалогу та порозуміння у реалізації освітньої політики.

Державно-громадське, державно-приватне і батьківське партнерство визначено авторами Концепції як один із стратегічних напрямів розвитку освіти дітей раннього та дошкільного віку. Ключовою у партнерських взаємовідносинах $€$ точка перетину спільних інтересів - здорова, щаслива і гармонійно розвинена дитина.

Співпраця органів влади й місцевого самоврядування з організаціями громадянського суспільства $€$ ознакою демократичного суспільства, у якому його потреби у різнобічному розвитку дітей раннього і дошкільного віку лежать в основі державної освітньої політики.

Державно-приватне партнерство у системі дошкільної освіти, особливо в умовах організації освіти дітей раннього віку - це новий досвід формування ринку дошкільних освітніх послуг, нові можливості для розширення прав громадян на вибір послуги, яка задовольняє їхні потреби і враховує можливості. Поштовхом до нової якості $€$ здорова конкуренція державного і приватного секторів дошкільної освіти. За умови налагодження конструктивної взаємодії влади, державного і приватного секторів можемо говорити про соціальне партнерство в управлінні дошкільною освітою.

Формування культури відповідального батьківства є також новим завданням, яке потребує підтримки держави і громадянського суспільства, науково-педагогічного супроводу i

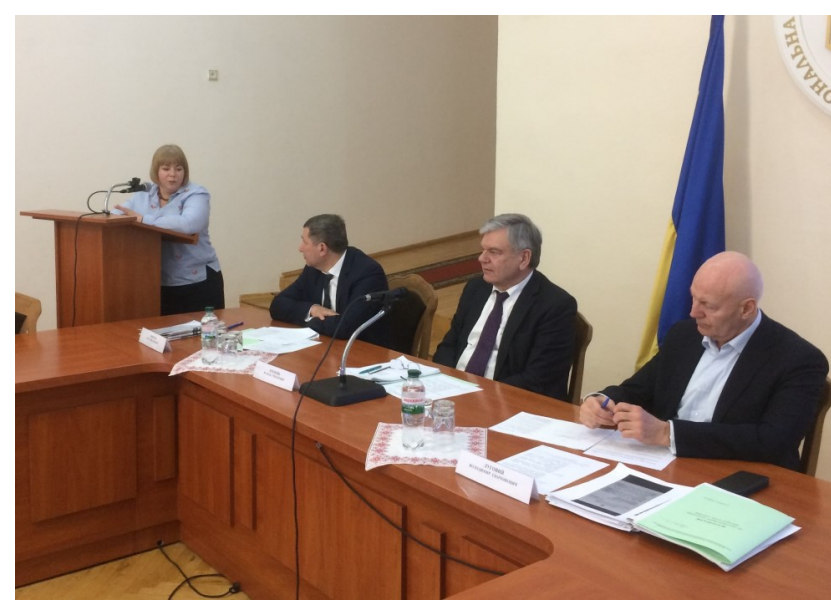

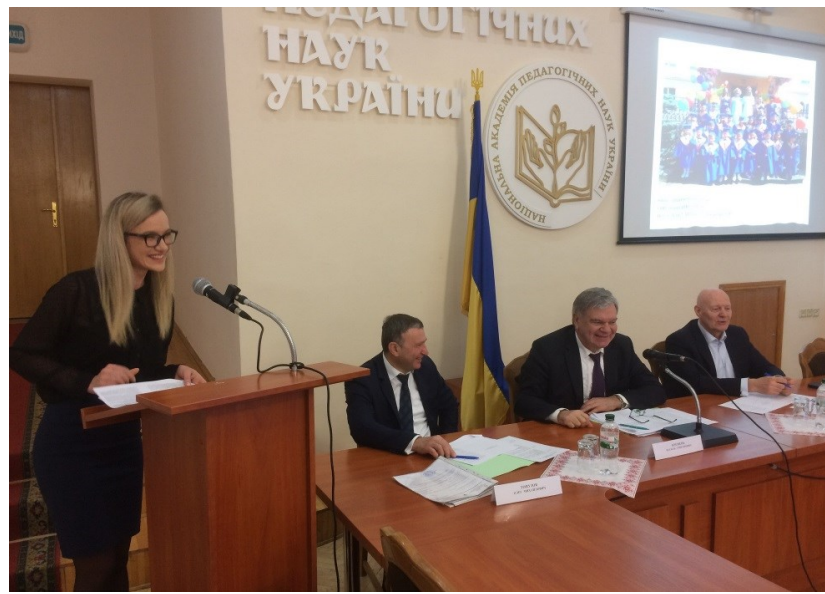

належного інформаційного забезпечення. Налагодження партнерських відносин з батьками дітей стає одним із найважливіших підходів у діяльності інституцій для досягнення спільних цілей, запорукою якісних змін у системі дошкільної освіти і суспільстві загалом.

У Концепції визначено стимули для розвитку партнерства держави і батьків, що передбачають: відновлення психолого-педагогічного патронату дітей, які з різних причин не відвідують заклади дошкільної освіти, з метою виявлення потреб сімей у підтримці раннього розвитку дітей і їх навчання; розширення участі батьків у громадських об'єднаннях, піклувальних радах, громадських асоціаціях; психолого-педагогічне просвітництво батьків, зокрема із застосуванням інформаційно-комунікаційних технологій тощо.

Якісне, прогресивне партнерство у сфері освіти дітей раннього і дошкільного віку будується на зацікавленні кожної зі сторін у результаті спільної діяльності у межах сфери своєї відповідальності.

Забезпечення якості дошкільної освіти: умови та інструменти оцінювання

Поліфункціональність поняття якості полягає у тому, що воно має три виміри (як це подано у «Списку використаних термінів»): якість дошкільної освіти, якість освітнього процесу та якість результату дошкільної освіти.

Якість освітнього процесу встановлюють за рівнем його відповідності державним вимогам, нормам і стандартам. Якість результату засвідчують досягнення дитини і показники ії особистісного зростання.

Якість дошкільної освіти є багатоаспектним і багаторівневим поняттям, яке визначають за сукупністю критеріїв: цілепокладання (оцінка цілей і завдань на всіх рівнях освітньої діяльнос- 


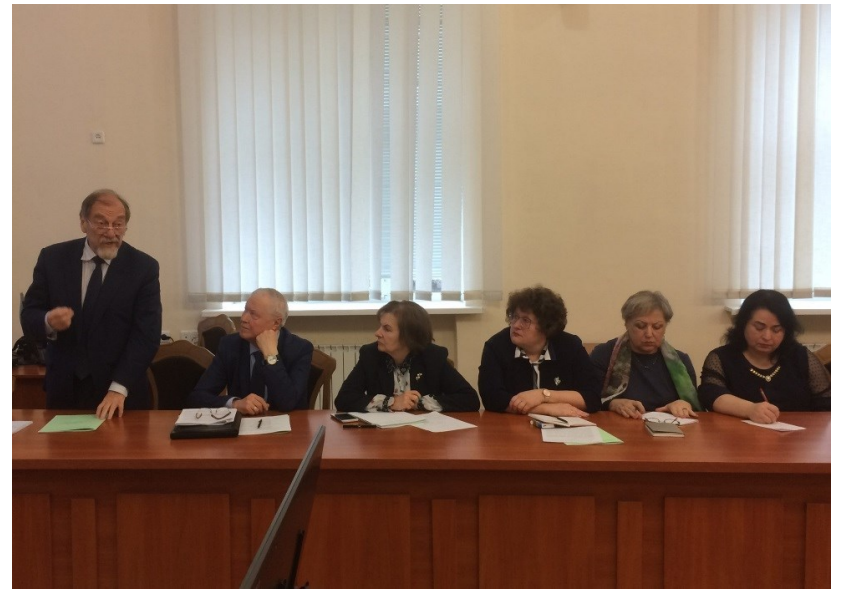

ті); умови для ефективного розв'язання освітніх завдань (матеріально-технічне, кадрове забезпечення методичне забезпечення освітнього процесу, створене предметно-ігрове середовище тощо); управління освітнім процесом, під час якого у дитини розвиваються життєво необхідні навички та базові особистісні якості (оцінювання механізмів та інструментів оптимальної організації надання освітніх послуг для задоволення потреб батьків, суспільства і держави); резульmam як рівень особистісних досягнень дитини тощо.

Орієнтиром якості результатів дошкільної освіти України, як це зазначено у Концепції, $\epsilon$ Базовий компонент дошкільної освіти як державний стандарт забезпечення якості.

Інституційний аудит - основний із інструментів зовнішнього оцінювання якості, який забезпечує реалізацію державної освітньої політики і дотримання стандарту, а також спрямовує заклади дошкільної освіти на постійне удосконалення діяльності. Стан і самопочуття дітей в освітньому процесі, динаміка особистісних досягнень старших дошкільників і формування у них базових компетентностей, важливих для подальшого розвитку на наступних рівнях освіти, мають стати предметом моніторингу якості роботи груп раннього та дошкільного віку (молодший і середній дошкільний вік).

Забезпечення фізичного, психічного та соціального здоров'я дітей $€$ ще одним напрямом розвитку дошкільної освіти, умовою організації освітнього середовища для дітей раннього і дошкільного віку, а також результатом ефективної і дієвої вітчизняної системи. Функція збереження здоров'я дитини має пронизувати освітній процес, в якому дотримується баланс між фізичним, емоційним, соціальним та інтелектуальним розвитком, наголошують автори Концепції. Створення у закладах дошкільної освіти атмосфери захищеності, психологічного комфорту, комплексне використання традиційних засобів фізичного виховання, нетрадиційних загартувальних процедур і проведення спеціальних лікувально-профілактичних заходів забезпечують реалізацію здоров' язбережувальної функції освіти.

У Концепції пропонується провести психологопедагогічну і гігієнічну експертизу освітніх програм щодо відповідності обсягу, змісту, організації освітнього процесу віковим, індивідуальним можливостям дітей. Медіапродукція, ігрове обладнання і дидактичне забезпечення також потребують додаткової психологічної експертизи.

Згідно з Концепцією передбачено організацію здорового харчування та постійний моніторинг контроль за його якістю, дотриманням вимог санітарно-гігієнічного та протиепідемічного режимів у закладах дошкільної освіти. Пропонується модернізувати технологічне обладнання харчових блоків та оновити раціони так, щоб вони задовольняли потреби організму дитини у якісному харчуванні.

Формування професійної компетентності педагогічних працівників також визначено авторами Концепції як важливу умову якісної дошкільної освіти. Побудова освітнього простору в закладі дошкільної освіти, суголосного 3 цінностями гуманістичної філософії та педагогіки, активне і цілеспрямоване залучення дітей до проєктної, ігрової, дослідно-пошукової видів діяльності, застосування багатьох форм і методів їх організації можливі за умови професіоналізму педагогічних працівників.

Професіоналізм педагога ототожнюється із його теоретичною і фаховою підготовленістю,

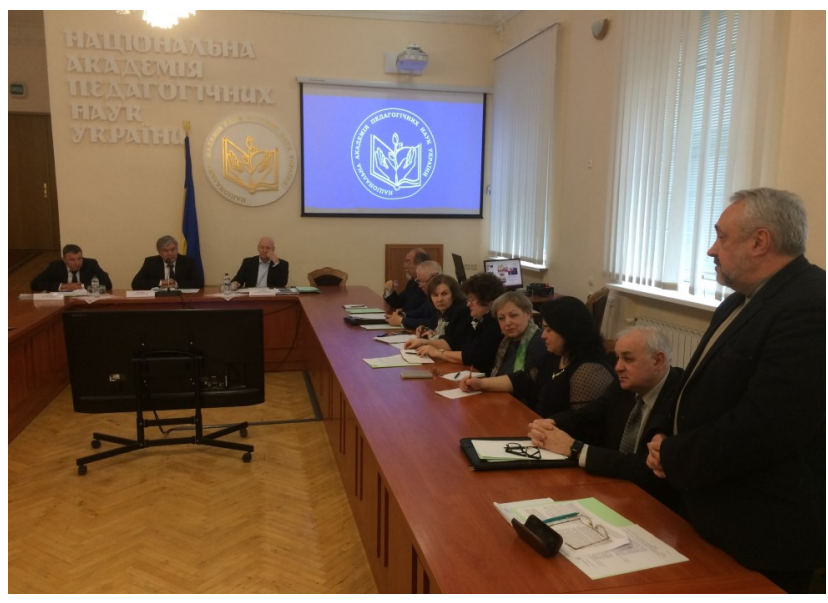




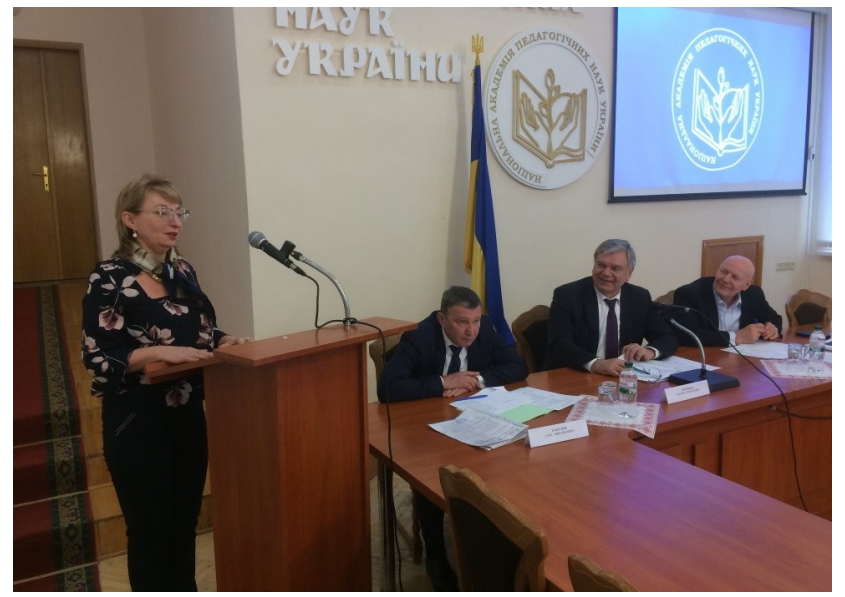

професійною компетентністю, моральними й особистісними якостями. Автори Концепції наголошують, що гуманістичні цінності освіти, ідеї особистісно орієнтованої педагогіки, педагогіки розуміння та партнерства, технології психологопедагогічної підтримки становлять підґрунтя професійної підготовки майбутніх педагогічних працівників закладів дошкільної освіти. Запровадження змін в освіті значною мірою залежатиме від вмотивованості освітян.

Концепція пропонує реформу системи післядипломної педагогічної освіти за змістом і формально-процесуальними характеристиками, демонополізацію й урізноманітнення ії за формами здобуття. Автори Концепції також акцентують на необхідності спеціальної психологопедагогічної підготовки працівників для роботи 3 дітьми з особливими освітніми потребами. Необхідні відновлення й практика наставництва як механізму підтримки молодих педагогів на етапі адаптації до діяльності в умовах закладу дошкільної освіти.

Синергія педагогічної науки і практики доикільної освіти

Незаперечним є значення педагогічної науки для теорії і практики дошкільного виховання. Але результати сучасних наукових досягнень у сфері медицини, педагогіки та психології не повною мірою впроваджуються у реальну ситуацію життєзабезпечення дитини раннього та дошкільного віку.

У Концепції запропоновано створити міждисциплінарний центр освіти дітей раннього та дошкільного віку в системі НАПН України, діяльність якого сприятиме імплементації наукових надбань у площину практичної роботи закладів дошкільної освіти. Напрями діяльності центру будуть спрямовані на консолідацію спільних зусиль сім'ї, держави та наукових установ: підготовку необхідної нормативно-правової бази; науково-методичне забезпечення психологопедагогічного та медичного патронату сім'ї, де виховуються діти раннього та дошкільного віку; розроблення стандарту якості дошкільної освіти та державного стандарту дошкільної освіти України - Базового компоненту дошкільної освіти.

Очікувані результати упровадження Концепції ма управління ризиками

Очікувані результати - це конкретні позитивні зміни, які відбудуться у сфері дошкільної освіти в результаті реалізації Концепції за умови прийняття відповідних нормативно-правових актів, належного ресурсного забезпечення та максимального визначення можливих ризиків для їх подальшої мінімізації або усунення.

У четвертому розділі Концепції викладено якісні зміни, які прогнозовано свідчать про успішність реформування освіти дітей раннього та дошкільного віку:

- доступна, якісна дошкільна освіта;

- збалансована система сімейного та суспільного виховання дитини раннього (від народження до трьох років) і дошкільного віку;

- дієвий психолого-педагогічний супровід дітей раннього та дошкільного віку із особливими освітніми потребами;

- наступність між дошкільною та початковою освітою в умовах Нової української школи.

Результативність упровадження Концепції вимірюється: рівнем правової, медичної та психолого-педагогічної обізнаності батьків щодо піклування та освітнього розвитку дітей раннього та дошкільного віку; ефективною системою контролю та профілактики здоров'я дітей; розширеним доступом до новітніх засобів та освітніх технологій у дошкільній освіті; якісною системою підготовки та перепідготовки педагогічних працівників закладів дошкільної освіти.

Управління ризиками передбачає всебічний аналіз сукупності ризиків, їх ідентифікацію, оцінку і вироблення механізмів контролю. Дошкільна освіта як складна синергетична система може перебувати у стані нерівноваги, сталого або динамічного розвитку, детермінованих низкою зовнішніх і внутрішніх факторів. Реформуючи дошкільну освіту України, а саме на це спрямовує Концепція, маємо враховувати ризики, пов'язані з іï ухваленням, а також оцінювати їх вплив на 
систему дошкільної освіти як основу формування людського капіталу.

Перша група ризиків лежить у площині відповідальності держави і органів виконавчої влади за достатнє фінансування галузі, забезпечення якості дошкільної освіти. Індикатори іншої групи ризиків - це стан готовності сім'ї та громадських, зокрема педагогічних спільнот, посилювати вимоги до якості освіти дітей раннього та дошкільного віку. До цієї групи відносять також низький соціальний статус педагогічних працівників і недостатній рівень їх підготовленості до організації роботи з різними віковими групами дітей.

На думку авторів, потребує розроблення «Дорожня карта» упровадження Концепції освіти дітей раннього та дошкільного віку, в якій будуть враховані етапність її реалізації, шляхи фінансового забезпечення і необхідність пілотування окремих положень. На етапі підготовки «Дорожньої карти», а особливо на етапі її реалізації суб'єктами управління системою дошкільної освіти, треба конкретизувати комплекс заходів, спрямованих на підвищення результативності їх діяльності та мінімізацію (усунення) можливих втрат (збитків) у процесі тих або інших видів діяльності.

У період глобалізованого високотехнологічного інформаційного суспільства основні положення Концепції освіти дітей раннього та дошкільного віку (проєкт) визначають стратегічні напрями освітнього розвитку на засадах дитиноцентризму дітей від народження до шкільного віку.

Дошкільна освіта є самоцінною, первинною ланкою системи безперервної освіти, що закладає підгрунтя когнітивного, соціального, емоційного та фізичного розвитку особистості дитини для ії̈ навчання упродовж життя.

Охоплення дітей раннього віку дошкільною освітою на основі визначених у Концепції цінностей і принципів дасть змогу виправити ситуацію щодо недостатнього використання когнітивних, фізіологічних, психологічних можливостей дитини від одного до трьох років для ії̈ повноцінного розвитку протягом подальшого життя.

Українське суспільство і громадяни України очікують від держави підтримки дошкільної освіти як економічно ефективної сфери надання і споживання освітніх послуг. Вектор дошкільної освіти, спрямовуючись у площину цінностей розвитку дитини, доступності, соціальної відпові-

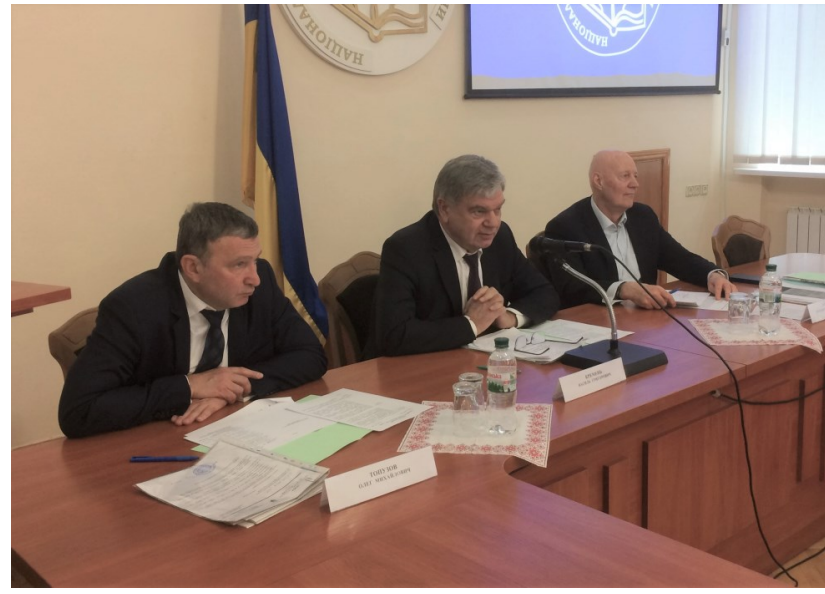

дальності всіх суб'єктів, зумовлює необхідність ефективних інвестицій у ранній розвиток дитини.

Гідне інвестування освіти дітей раннього віку і фінансування оплати праці педагогів - це інвестування у людський капітал, який має забезпечити економічний розвиток нашої країни, підвищити рівень і якість життя населення.

Соціальне значення Концепції освіти дітей раннього та дошкільного віку полягає у їі спрямованості на створення загального соціопростору солідарної відповідальності батьків, педагогів і державних службовців за якість дошкільної освіти як стратегічного ресурсу реалізації цілей сталого розвитку суспільства.

\section{СПИСОК ВИКОРИСТАНИХ ДЖЕРЕЛ}

Воронов, В.А., Гавриш, Н.В., Канішевська, Л.В., Піроженко, Т.О., Рейпольська, О.Д., \& Сисоєва, С.О. (Укл.). Концепція освіти дітей раннього та дошкільного віку (проєкт) (2020). НАПН України. Київ. httр:// naps.gov.ua/ua/press/announcements/1763/

Дошкільна освіта в Україні у 2018 році. Cтатистична інформація (2019). Державна служба статистики України.. http://www.ukrstat.gov.ua/

Кодекс законів про працю України : Закон України від 10.12.1971 р. № 22-VIII; зі змінами і доповненнями 1972-2020 pp. https://zakon.rada.gov.ua/laws/ show/322-08

Про дошкільну освіту : Закон України від 11.07.2001 p. № 2628-III; зі змінами і доповненнями 20012020 pp. https://zakon.rada.gov.ua/laws/show/2628-14 International Standard Classification of Education. ISCED 2011 (2012). UNESCO Institute for Statistics. http:// uis.unesco.org/sites/default/files/documents/ international-standard-classification-of-educationisced-2011-en.pdf

OECD (2019). Providing Quality Early Childhood Education and Care. Results from the Starting Strong Survey 2018. https://doi.org/10.1787/301005d1-en

UNICEF (2013). Evidence for ECD Investment. https:// www.unicef.org/earlychildhood/index_69851.html

(C) Фото: О.А. Шагаєва 


\section{THE CONCEPT OF EARLY CHILDHOOD AND PRESCHOOL EDUCATION: A NEW LOOK}

Scientific report at the Meeting of the Presidium of the National Academy of Educational Sciences of Ukraine, February 27, 2020

Svitlana Sysoieva

DSc in Pedagogy, Professor, Full Member (Academician) of NAES of Ukraine, Academician Secretary of the Division of General Pedagogy and Philosophy of Education, National Academy of Educational Sciences of Ukraine, Kyiv, Ukraine

Olha Reipolska

PhD in Pedagogy, Associate Professor, Head of the Preschool Education Laboratory, Institute of Problems on Education of the National Academy of Educational Sciences of Ukraine, Kyiv, Ukraine

Abstract. The main statements of the draft Concept of Early Childhood and Preschool Education are presented; it was considered at the Meeting of the Presidium of the National Academy of Educational Sciences of Ukraine on February 27, 2020 and published for discussion on the NAES of Ukraine official website. The Concept's aim is to ensure the systemic changes in early childhood and preschool education, preschool education administration at its various levels in order to develop the country's strategic resource - the qualitative human capital. The Concept's relevance is grounded; its structure is presented; its five chapters are characterized: "The State of Early Childhood and Preschool Education in Ukraine", "Strategic Directions of the Early Childhood and Preschool Education Development", "Legislative and Administrative Prerequisites of the Concept Realization", "Financing", "Expected Outcomes", "Risks" and a Glossary. Conceptual bases of the system of preschool education modernization are developed on the initiative of the NAES of Ukraine researchers and lawmakers, as well as with participation of academic staff and educators. Among the Concept's authors are: Volodymyr Voronov, Head of the Subcommittee on Early Development and Preschool Education of the Verkhovna Rada of Ukraine Committee on Education, Science and Innovations; Nataliia Havrysh, Chief Research Fellow of the Preschool Education Laboratory, Institute of Problems on Education of NAES of Ukraine, DSc in Pedagogy, Professor; Liubov Kanishevska, Deputy Director for Scientific and Experimental Work, Institute of Problems on Education of NAES of Ukraine, DSc in Pedagogy, Professor; Tamara Pirozhenko, Head of the Laboratory of Preschooler Psychology, G.S. Kostiuk Institute of Psychology of NAES of Ukraine, DSc in Psychology, Professor, Corresponding Member of NAES of Ukraine; Olha Reipolska, Head of the Preschool Education Laboratory, Institute of Problems on Education of NAES of Ukraine, PhD in Pedagogy, Associate Professor; Svitlana Sysoieva, Academician Secretary of the Division of General Pedagogy and Philosophy of Education, National Academy of Educational Sciences of Ukraine, DSC in Pedagogy, Professor, Full Member (Academician) of NAES of Ukraine.

Keywords: childcentrism; early childhood; early childhood education; parent partnership; pedagogical and psychological support; preschool education institutions; preschool education quality.

Дата публікації: 2 березня 2020 р. 